Vol.2 No.1, Agustus 2019

\title{
PERANCANGAN DAN EVALUASI SISTEM TRANSAKSI ONLINE PASAR TRADISIONAL MENGGUNAKAN METODE GOAL DIRECTED DESIGN DAN EVALUASI HEURISTIK
}

\author{
(Design and Evaluation Of Traditional Market Online Transaction Systems Using Methods Goal \\ Directed Design and Heuristic Evaluation) \\ Ulia Niati $^{1}$, Tri Suratno ${ }^{2}$, Mauladi $^{3}$ \\ Program Studi Sistem Informasi Fakultas Sains dan Teknologi Universitas Jambi* \\ Jl. Jambi-Ma. Bulian KM 15 Mendalo Darat Jambi 36361 \\ Email: ulianiati27@gmail.com
}

\begin{abstract}
Today the development of technology is growing, one of them is a mobile phone that is transformed into a smart phone, as well as a modern market that is developing and easily available and very comfortable physically, this development has involved traditional markets, the government continues to revitalize traditional markets using physical, technological developments are used as a means for developing traditional markets as an effort to facilitate transactions, get information quickly and on target. User interface Of course not separated from the appearance of the user interface Even the user interface is important, because the user interface can provide comfort and convenience for users in accessing any information for which the system can be obtained by the user. The purpose of this research is to create a traditional market online transaction system user interface. Where the research used in this study is the Goal Directed Design method which is a user interface design design method that fits the user's goals and needs. In this study there are five stages of experimental research, modeling, requirements, frameworks, and improvements. As well as the evaluation in this study using heuristic evaluation consisting of 10 principles. The final result of this study is a user interface design design that has been created for further development while the results of this study are $94 \%$ in the category of "Very Good".
\end{abstract}

Keyword: Goal Directed Design, Heuristic Evaluation, User Interface

\section{PENDAHULUAN}

Pasar merupakan salah satu dari berbagai sistem, institusi, prosedur, hubungan sosial dan infrastruktur dimana usaha menjual barang, jasa dan tenaga kerja untuk orangorang dengan imbalan uang. Menurut Peraturan Presiden Republik Indonesia Nomor 112 Tahun 2007 mengenai penataan dan pembinaan pasar tradisional, pusat perbelanjaan dan toko modern menyebutkan pasar adalah area tempat jual beli barang dengan jumlah penjual lebih dari satu baik yang disebut sebagai pusat perbelanjaan, pasar tradisional, pertokoan, mall, plaza, pusat perdagangan, maupun sebutan lainnya.

Pasar sudah menjadi suatu komponen penting dalam kehidupan terutama untuk fasilitas umum yang digunakan sebagai tempat transaksi jual beli secara langsung dan tidak langsung dengan pedagang, pembeli, serta barang yang akan dijual dan tentunya pasar begitu akrab dengan lingkungan masyarakat, baik dikota maupun didesa. Berdasarkan klasifikasinya pasar terbagi menjadi dua yaitu pasar modern dan pasar tradisional. Kondisi pasar kian berkembang baik itu pasar modern berupa mall, minimarket, dan maupun pasar tradisional itu sendiri.

Banyak bermunculan tempat-tempat berbelanja untuk kebutuhan sehari-hari seperti mall, hypermart, minimarket, supermarket, dan lain-lain yang menjadi pusat perbelanjaan. Perkembangan pasar modern tersebut mengakibatkan perubahan yang mempengaruhi kehidupan masyarakat salah satunya perubahan tempat belanja masyarakat 
(Fatra, 2018). Tidak sedikit konsumen yang merubah perilaku belanjanya dari pasar tradisional pindah, coba-coba (trial), dan cari alternatif (switching) ke pasar modern. Hal ini wajar karena kondisi pasar tradisional selalu identik dengan becek, semrawut, kurang nyaman. Kelemahan dari pasar tradisional inilah yang menjadi daya jual bagi pasar modern yang menyediakan tempat yang nyaman, teratur, bergengsi, ber-AC, aman, bersih dan pembeli bisa memilih barang dengan leluasa. (Guspul, 2015)

Meskipun pertumbuhan pasar modern semakin menjamur, bukan berarti pasar tradisional ditinggalkan begitu saja oleh masyarakat. Masih ada masyarakat yang mengandalkan pasar tradisional sebagai tempat untuk memenuhi kebutuhan pangan dan sandang nya setiap hari (Novita et al., 2017). Pemerintah pun terus berusaha memperbaiki fisik pasar tradisional dengan memperbaiki fasilitas pasar yang ada, merevitalisasi agar fungsi dapat lebih optimal, membenahi manajemennya serta perilaku pedagang.

Perkembangan teknologi yang kian tinggi dan dikenal dengan era digital tentunya menjadi peluang bagi pasar tradisional untuk mengembalikan peranannya dengan cara mengkolaborasikan pasar tradisional menggunakan teknologi. Era teknologi modern seperti saat ini yang semakin berkembang dapat menjadi jembatan transaksi di pasar tradisional tanpa harus pergi ke pasar namun setiap sistem tersebut dapat memunculkan keresahan kembali jika tidak sesuai dengan kebutuhan pengguna dan buruknya tampilan user interface bahkan dapat ditinggalkan oleh penggunanya. Untuk itu diperlukan perancangan desain user interface yang tepat dan sesuai dengan tujuan pengguna yang dapat menjembatani pengguna dan sistem.

Sehingga penulis tertarik untuk melakukan perancangan user interface untuk sistem transaksi online pasar tradisional dengan menggunakan metode perancangan yang bertujuan pada pengguna. Adapun tujuan penelitian ini adalah membuat sebuah rancangan user interface sistem transaksi online pasar tradisional dengan metode Goal
Directed Design yang sesuai dengan tujuan pengguna. Goal Directed Design ialah salah satu metode untuk perancangan user interface yang berdasarkan dari tujuan user dalam menggunakan suatu aplikasi, sehingga user akan lebih mudah dalam menggunakan aplikasi. (Sabariah et al., 2016).

Selanjutnya setelah dilakukan perancangan maka akan dilakukan evaluasi pada perancangan yang telah dirancang dengan menggunakan evaluasi heuristic. Evaluasi heuristic ialah metode rekayasa kegunaan untuk menemukan masalah kegunaan dalam desain antarmuka pengguna (Nielsen, 1994). Evaluasi dilakukan dengan 10 prinsip heuristic diantaranya; Visibility of system status, Match between system and the real world, User control and freedom, Consistency and standards, Error prevention, Recognition rather than recall, Flexibility and efficiency of use, Aesthetic and minimalist design, Help user recognize, diagnose, and recover from errors dan Provision of help and documentation. (Neilsen, 1994).

\section{METODOLOGI PENELITIAN}

Penelitian yang dilakukan merupakan jenis penelitian deskriptif kualitatif dimana pada data yang sudah dikumpulkan dari hasil penelitian di tuangkan pada penyajian data kedalam bentuk tabel. Penelitian dilakukan di Pasar Tradisional Angso Duo Jambi yang beralamat di Jl. Sultan Thaha, Beringin, Ps. Jambi, Kota Jambi, Jambi 36124.

\section{Tempat dan Waktu Penelitian}

Tempat yang dipilih sebagai tempat penelitian adalah di Pasar Tradisional Angso Duo Jambi yang beralamat di Jl. Sultan Thaha, Beringin, Ps. Jambi, Kota Jambi, Jambi 36124. Waktu yang digunakan penulis untuk melakukan penelitian terhitung sejak Agustus 2018 - April 2019.

\section{Alat dan Bahan Penelitian}

Alat yang dibutuhkan pada penelitian ini adalah sebagai berikut:

a. Perangkat keras (Hardware) berupa laptop dengan spesifikasi; prosesor Intel corel i3-3217U 1.80GHz RAM 4 GB, dan 
beberapa perangkat keras pendukung lainnya.

b. Perangkat lunak (Software) antara lain sistem operasi windows 7 ultimate 64 bit, web browser mozilla firefox 64.0.2, edraw 7.8 untuk merancang diagram, adobe photoshop CC 2017 untuk merancang mockup, dan boostrap studio 2.2.4 untuk merancang prototipe.

Adapun bahan yang digunakan dalam penelitian ini adalah:

a. Studi literatur dan tinjauan pustaka terkait dengan perancangan, user interface, metode goal directed design dan yang terkait lainnya.

b. Hasil wawancara dengan responden sebagai calon pengguna.

c. Hasil pengisian kuesioner penelitian terhadap rancangan user interface menggunakan evaluasi heuristik

\section{Metode Pengumpulan Data}

Pengumpulan data dilakukan dengan melakukan observasi objek penelitian, wawancara untuk mengidentifikasi kebutuhan pengguna, studi pustaka untuk mencari teori pendukung dan kuesioner terkait evaluasi heuristik.

\section{Kerangka Kerja Penelitian}

Dalam melakukan penelitian tentunya memerlukan adanya kerangka kerja ataupun langkah-langkah yang dilakukan dalam melakukan penelitian, kerangka kerja dalam penelitian ini menggunakan tahapan dari metode goal directed design dapat dilihat pada gambar dibawah ini:

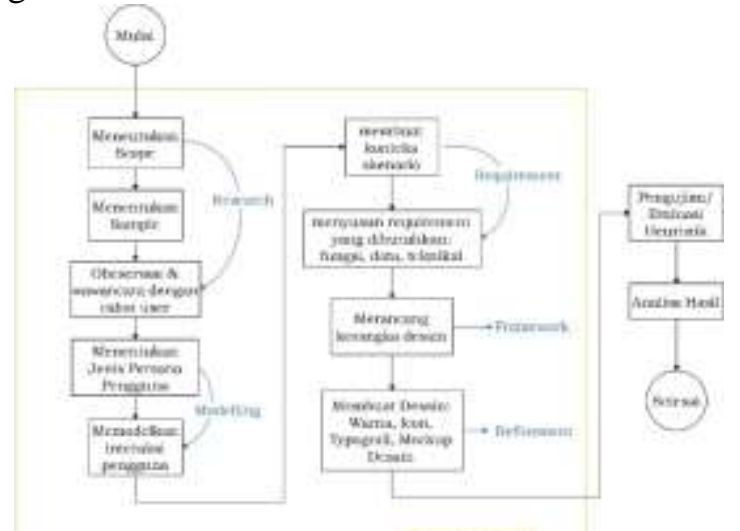

Gambar 1. Kerangka Kerja Penelitian
Berdasarkan pada gambar kerangka kerja diatas, maka berikut adalah penjelasan dari tahapan penelitian yaitu sebagai berikut:

1. Research dalam tahapan ini bertujuan untuk mendapatkan data secara kualitatif tentang pengguna dari aplikasi dan pada tahap ini terdapat beberapa bagian diantaranya:

a. Menentukan Scope.

b. Menentukan Sample.

c. Observasi dan wawancara dengan calon user.

2. Modeling, pada tahap ini dari data hasil research yang telah dilakukan akan ditentukan jenis persona dan memodelkan interaksi pengguna.

3. Requirement, membuat konteks skenario secara umum dari pola pengguna aplikasi dan menyusun fungsi, data, dan teknikal.

4. Framework, melakukan perancangan kerangka desain interaksi berisi mengenai tampilan, layout, informasi, tampilan atau mockup yang dibutuhkan dalam sistem transaksi online pasar tradisional.

5. Refinement, pada tahap ini akan dilakukan pembuatan visual style yang akan digunakan pada aplikasi pasar tradisional dengan warna, icon, tipografi, dan mockup desain yang mengambarkan aplikasi.

6. Pengujian/Evaluasi, setelah melakukan perancangan selanjutnya dilakukan evaluasi pada perancangan prototipe menggunakan evaluasi heuristic dengan menyebarkan kuesioner pada 5 (lima) orang evaluator yang memiliki keahlian dalam bidang komputer, yang dalam hal ini dituju pada 3 (tiga) orang dosen sistem informasi dan 2 (dua) orang programmer di LPTIK UNJA yang pernah berkecimpung dalam pembuatan, pembelajaran, dan memahami user interface, serta pernah berinteraksi dengan sistem.

7. Analisa Hasil

Pada tahap ini peneliti melakukan analisis hasil data dengan menghitung hasil kuesioner yang telah diisi oleh evaluator. Kemudian hasil analisis dimasukkan pada kategorinya.

\section{Teknik Analisis Data}

Analisis data pada penelitian ini menggunakan teknik analisis kualitatif 
deskriptif dan kuantitatif pada data yang telah dikumpulkan dari hasil penelitian. Analisa kualitatif dilakukan dengan interview, wawancara serta dokumentasi studi pustaka yang berkaitan dengan penelitian. Pada analisa kuantitatif dilakukan dengan menggunakan kuesioner, dimana yang dianalisa data hasil kuesioner yang telah diisi oleh evaluator dan selanjutnya dituangkan pada penyajian data kedalam bentuk tabel. Data yang dikumpulkan dihitung menggunakan Excel, kemudian hasil disajikan dalam bentuk persentase selanjutnya mendeskripsikan dan mengambil kesimpulan dari hasil persentase yang didapatkan.

\section{Instrumen Analisis Data}

Pengukuran dilakukan dengan menggunakan metode skala likert dengan 4 (empat) poin skala, yaitu:

Tabel 1. Skala Likert

\begin{tabular}{cc}
\hline Kriteria Skala Likert & Bobot \\
\hline Sangat Baik (SB) & 4 \\
Baik (B) & 3 \\
Tidak Baik (TB) & 2 \\
Sangat Tidak Baik & 1 \\
(STB) & \\
\hline
\end{tabular}

\section{HASIL DAN PEMBAHASAN}

\section{Research}

a. Menentukan Scope, ruang lingkup penelitian yang dilakukan adalah sebatas perancangan desain user interface sistem transaksi online pasar tradisional pengguna akhir yang berupa prototype.

b. Menentukan sample, dalam penelitian ini peneliti menggunakan teknik sample judgement sampling atau sering disebut purposive sampling. Alasan penggunaan sample tersebut dikarenakan cocok dengan penelitian yang dilakukan dimana sampel ditentukan atas kriteria tertentu. Sample wawancara yang menjadi kriteria adalah perempuan, pernah berbelanja di pasar tradisional, kisaran umur $18-60$ tahun dan profesi mahasiswa, pekerja dan ibu rumah tangga. Dalam penelitian ini jumlah sampel yang digunakan sebanyak 10 orang, sample yang digunakan dapat juga kurang dari 10 jika sudah mencapai kejenuhan data (Jahja, 2017).

c. Melakukan observasi dan wawancara dengan calon pengguna untuk mengetahui tujuan dan motivasi calon pengguna, untuk mengetahui aktivitas yang dilakukan oleh calon pengguna, kemahiran menggunakan android, untuk mengetahui pendapat calon pengguna mengenai aplikasi mobile dalam berbelanja serta untuk mengetahui aspek desain dalam aplikasi.

\section{Modeling}

a. Menentukan jenis persona pengguna, berupa demographic, attitude, activity, device \& platform, expertise, goal and motivation dan action to achieve goals. Ada 3 (tiga) persona yang merepresentasikan tipe user diantaranya wanita pekerja, ibu rumah tangga dan mahasiswa.

b. Memodelkan interaksi pengguna, pada tahap ini dilakukan pemodelan interaksi pengguna dengan lingkungan dalam mencari informasi harga barang ataupun keperluan sejenisnya dalam pasar tradisional seperti berikut ini:

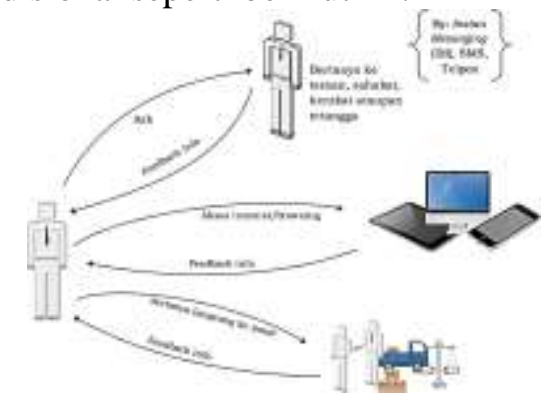

Gambar 2. Workflow interaksi penguna dengan lingkungan untuk mendapatkan informasi

\section{Requirement}

a. Membuat konteks skenario, Konteks skenario dalam requirement merupakan suatu aktivitas yang mencerminkan tujuan dalam berinteraksi dengan sistem. Konteks skenario dibuat untuk dijadikan sebagai kebutuhan dalam perancangan aplikasi. Konteks skenario dibuat berdasarkan hasil analisis kegiatan persona dalam kegiatan kesehariannya dalam mencari informasi ataupun barang dalam pasar tradisional yang berhubungan dengan kebutuhan sehari-hari baik itu pekerja, mahasiswa, ibu rumah tangga lainnya dalam berbelanja.

b. Menyusun requirement, diantaranya dibuat fungsi requirement mengenai apa saja yang disajikan pada aplikasi dalam hal ini ialah; login, pencarian barang, daftar belanja, daftar tersimpan, pemberitahuan, riwayat transaksi, 
bantuan, panduan, syarat pengguna, kebijakan privasi, tentang aplikasi dan logout yang digambarkan dalam bentuk use case diagram (lihat gambar 3). Pada data requirement; data pembeli, data barang, data transaksi, data informasi dan kategori yang digambarkan dalam class diagram (lihat gambar 4). Pada teknikalnya ialah diharapkan minimum perangkat mobile yang dibutuhkan prosesor Dual-core, Ram 1GB, resolusi layar 854x 480 serta Android versi 4.1 (jelly bean).

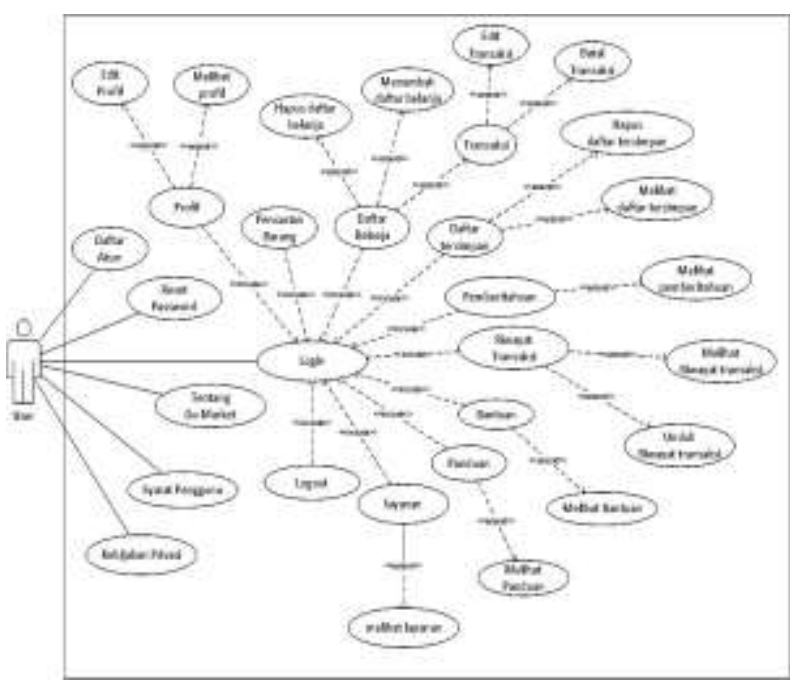

Gambar 3. fungsi requirement yang digambarkan menggunakan use case diagram sistem transaksi online pasar tradisional

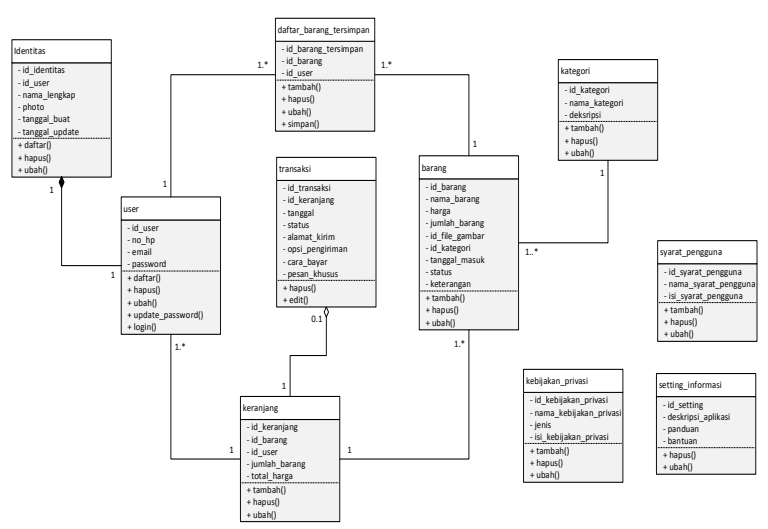

Gambar 4. Data requirement yang digambarkan dalam class diagram

\section{Framework}

a. Pada tahap ini dilakukan untuk membuat sketsa kasar dan behavior yang nantinya akan menyusun sebuah kerangka interaksi. Pada kerangka interaksi akan berisi mengenai struktur tampilan dan layout dari aplikasi serta informasi dari tampilan user interfacenya.

b. Pada framework terdapat penentuan posture dimana secara umum aplikasi mobile menggunakan gabungan dari dua posture yaitu sovereign posture dan transient posture. Dimana sovereign posture ialah suatu posture yang menarik perhatian pengguna dalam jangka waktu yang lama sedangkan transient posture ialah posture yang menyajikan sekelompok kecil set fungsi dan kontrol.

c. Merancang sketsa kerangka interaksi untuk membuat wireframe atau rancangan awal atau sebuah sketsa kasar dari user interface salah satunya sebagai berikut:

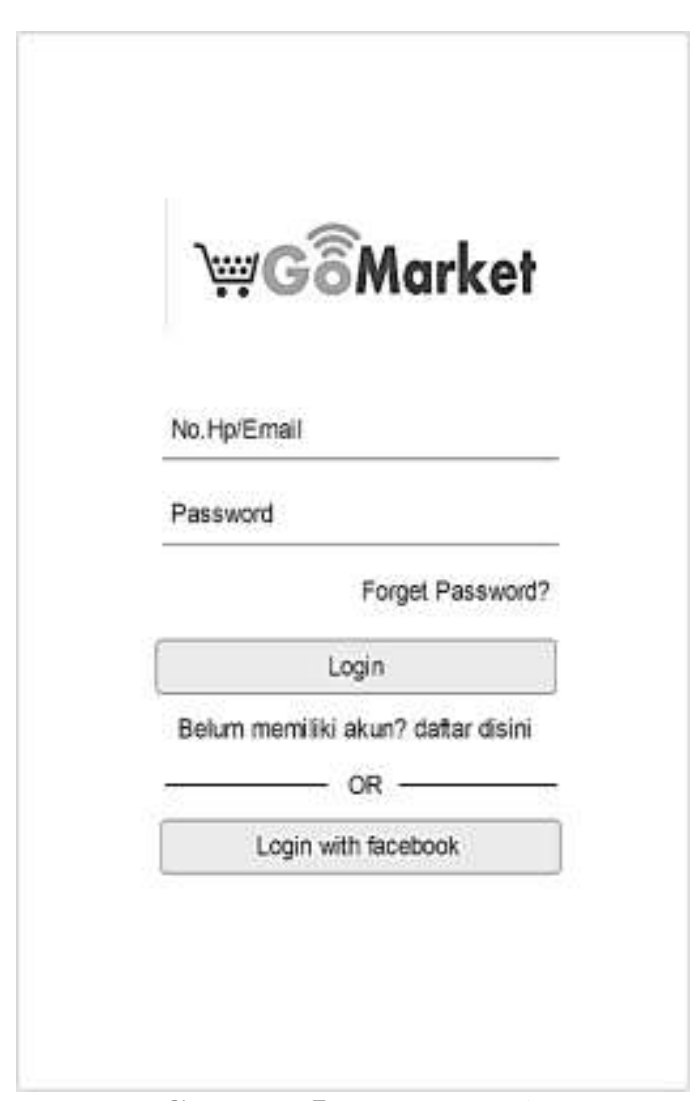

Gambar 5. Wireframe login 
Vol.2 No.1, Agustus 2019

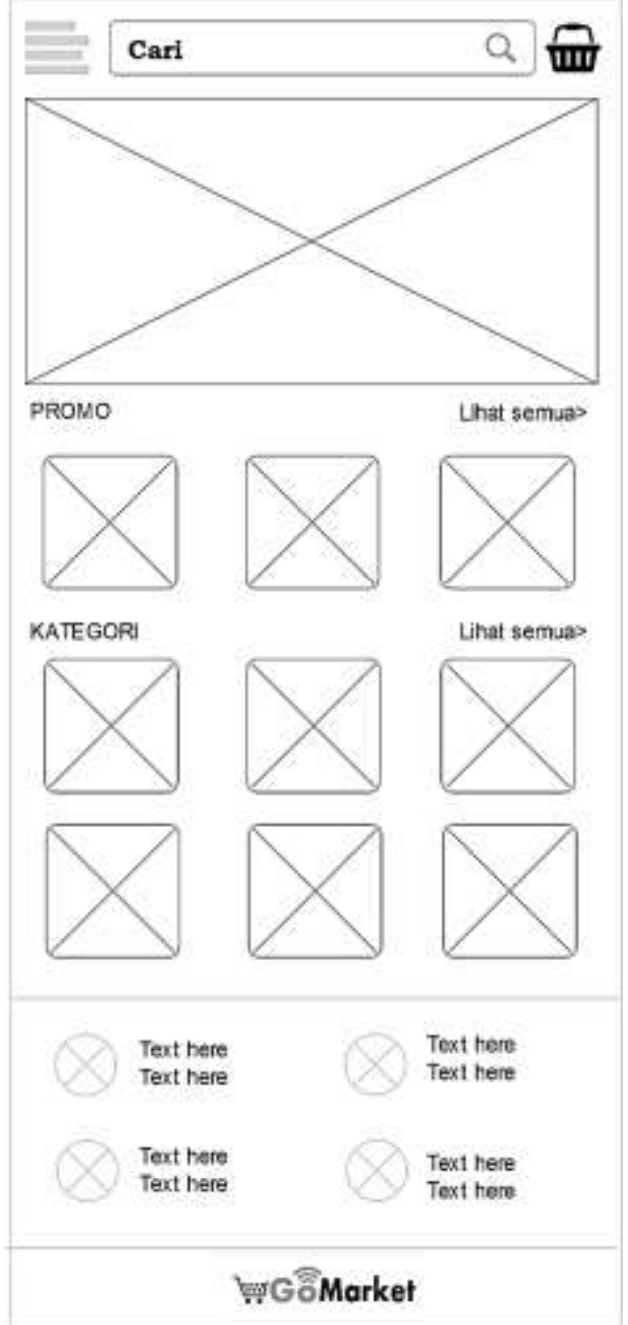

Gambar 6. Wireframe halaman utama.

\section{Refinement}

a. Pada tahap ini akan dibuat visual style sesuai dengan wireframe sebelumnya dengan tampilan aplikasi yang sederhana dan mudah digunakan. Perancangan visual style mempertimbangkan dan menyesuaikan warna yang biasanya dapat menggambarkan atau merepresentasikan dari suatu pasar tradisional.

b. Warna yang digunakan ada palet utama dan pendukung seperti dibawah ini;

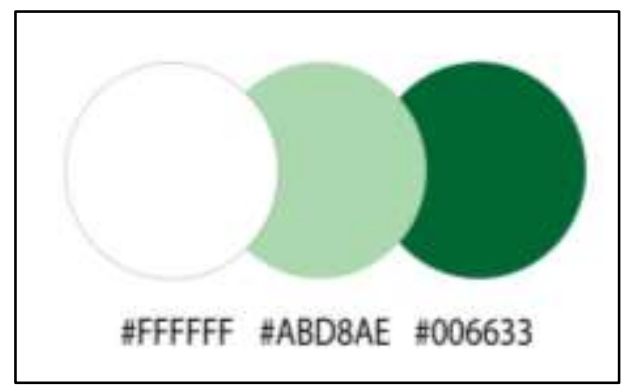

Gambar 7. Palet Warna Utama

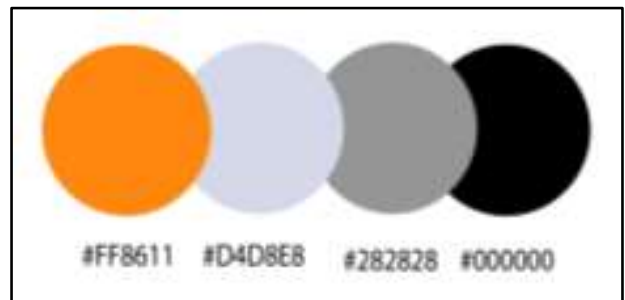

Gambar 8. Palet Warna Pendukung

c. Typeface dan tipografi yang digunakan ialah typeface default yang biasa digunakan pada aplikasi berplatfrom android yaitu roboto.

d. Icon, digunakan untuk merepresentasikan fungsi yang ada pada suatu menu dalam bentuk visual.

e. Mockup desain aplikasi dibuat dari rancangan sebelumnya yang akan dirancang kembali dengan menambahkan unsur visual style sehingga menghasilkan suatu perancangan desain user interface yang nantinya akan dibuat prototipe nya. Adapun beberapa tampilannya sebagai berikut:

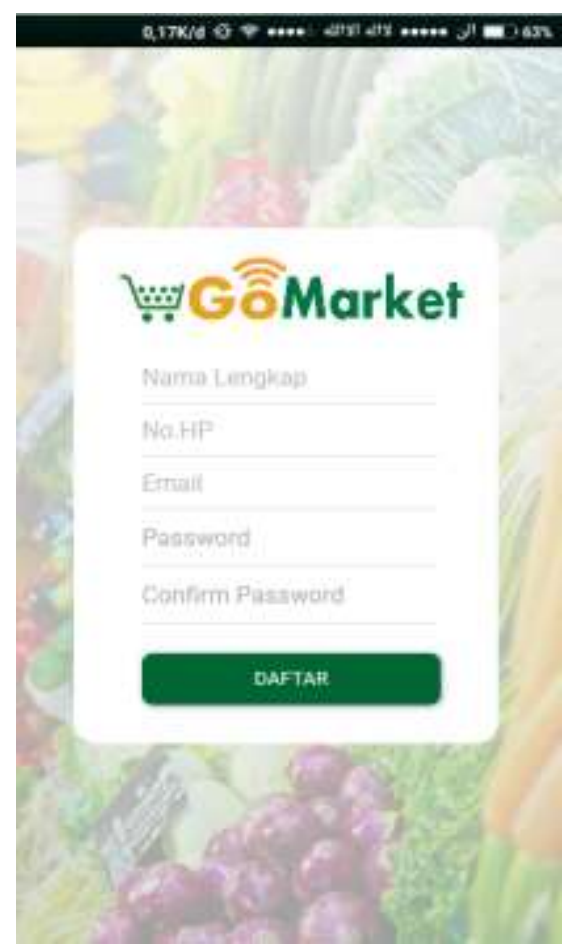

Gambar 9. Mockup Screen Daftar 


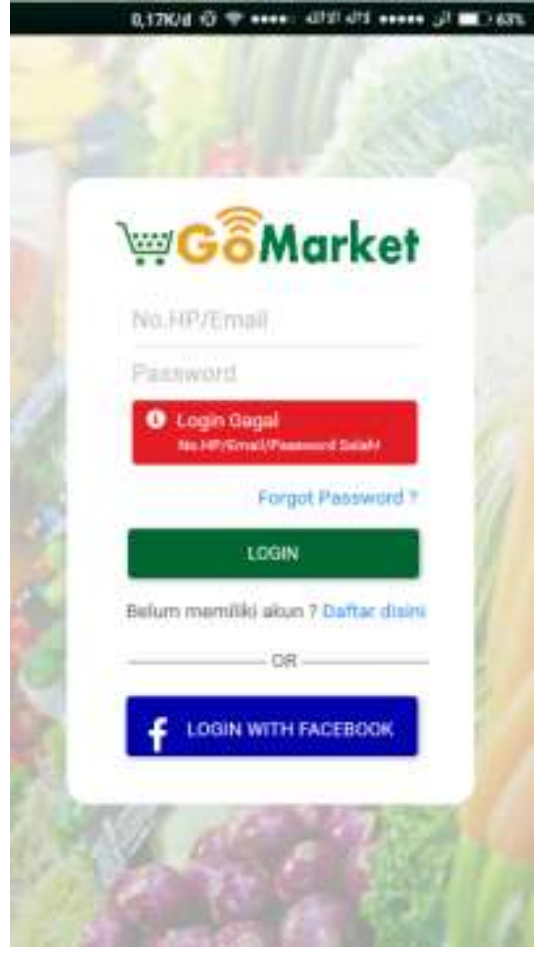

Gambar 10. Mockup Screen Gagal Login

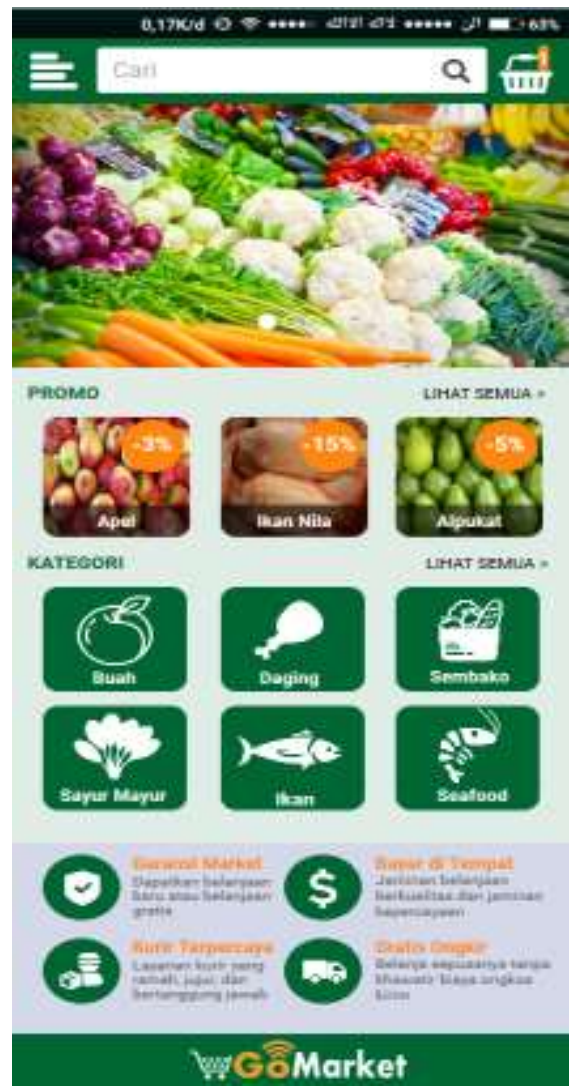

Gambar 11. Mockup Halaman Awal

\section{Evaluasi}

Pada tahap ini peneliti melakukan evaluasi terhadap prototipe yang telah didesain. Evaluasi ini dilakukan dengan penyebaran kuesioner kepada 5 (lima) orang evaluator, masing-masing evaluator mengisi sebanyak 37 indikator untuk 10 variabel berdasarkan prinsip heuristic, sebelum mengisi kuesioner evaluator terlebih dahulu mencoba dan melihat desain prototipe yang telah dibuat dengan aplikasi bootstrap studio dengan format html pada web browser mozilla firefox. Adapun hasil evaluasi sebagai berikut:

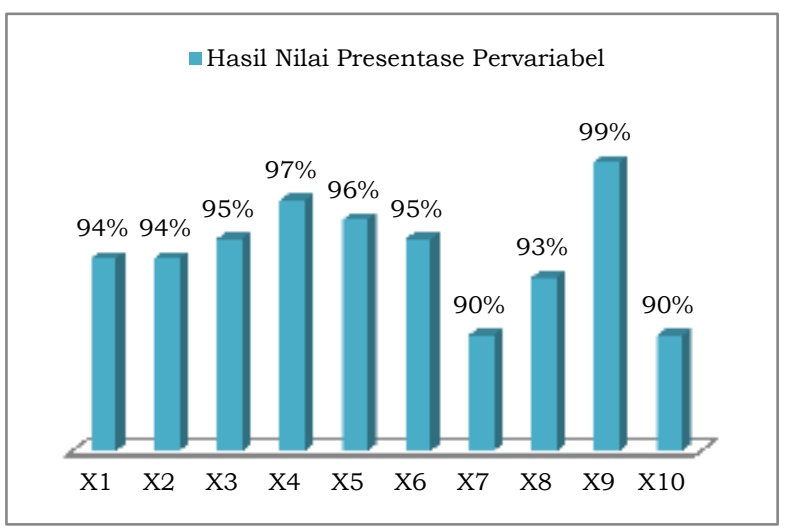

Gambar 12. Hasil nilai persentase pervariabel

Tabel 2. Rekap hasil evaluasi heuristic

\begin{tabular}{|c|c|c|c|c|c|}
\hline NO & Variabel & $\begin{array}{l}\text { Skor } \\
\text { total }\end{array}$ & $\begin{array}{l}\text { Skor } \\
\text { ideal }\end{array}$ & $\%$ & Ket \\
\hline 1 & $\mathrm{X} 1$ & 131 & 140 & $94 \%$ & SB \\
\hline 2 & $\mathrm{X} 2$ & 75 & 80 & $94 \%$ & SB \\
\hline 3 & X3 & 57 & 60 & $95 \%$ & SB \\
\hline 4 & $\mathrm{X} 4$ & 58 & 60 & $97 \%$ & SB \\
\hline 5 & $\mathrm{X} 5$ & 77 & 80 & $96 \%$ & SB \\
\hline 6 & X6 & 57 & 60 & $95 \%$ & SB \\
\hline 7 & X7 & 36 & 40 & $90 \%$ & SB \\
\hline 8 & X8 & 56 & 60 & $93 \%$ & SB \\
\hline 9 & X9 & 79 & 80 & $99 \%$ & SB \\
\hline 10 & $\mathrm{X} 10$ & 72 & 80 & $90 \%$ & SB \\
\hline \multicolumn{2}{|c|}{ Total } & 698 & 740 & $94 \%$ & SB \\
\hline
\end{tabular}

Berdasarkan tabel 54 diatas maka dapat dilihat hasil pervariabelnya dan setiap variabel nya masuk dalam kategori interval sangat baik seperti dijelaskan sebelumnya. Dengan demikian persentase total akhir adalah 94\% maka hasil evaluasi heuristic terhadap prototipe user interface yang dirancang masuk kedalam interval "Sangat Baik" Berdasarkan hasil akhir yang didapatkan dapatlah kesimpulan bahwa desain sistem transaksi pasar tradisional yang telah dirancang layak untuk direkomendasikan sebagai user interface sistem transaksi online pasar tradisional. 
Vol.2 No.1, Agustus 2019

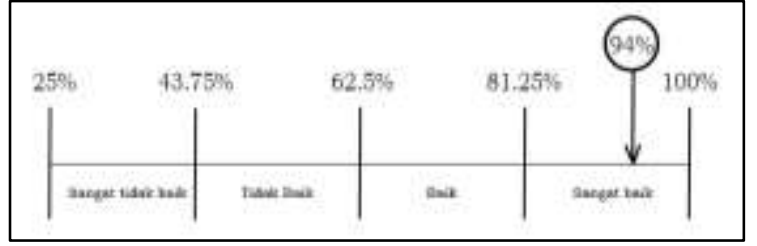

Gambar 13. Nilai Persentase akhir dari evaluasi heuristic

\section{KESIMPULAN DAN SARAN KESIMPULAN}

Berdasarkan pembahasan yang telah diuraikan maka kesimpulan dari penelitian ini ialah setiap penelitian pengembangan melakukan suatu perancangan terlebih dahulu, dalam penelitian ini perancangan sistem transaksi online pasar tradisional dilakukan dengan metode goal directed design (GDD). Perancangan menggunakan metode GDD dapat diterapkan dalam perancangan sistem transaksi online pasar tradisional. Metode GDD merupakan sebuah metode perancangan user interface yang berdasarkan tujuan dari sisi user untuk menggunakan suatu aplikasi, sehingga pengguna dapat menggunakan aplikasi secara efisien. Pada penelitian ini metode GDD dapat digunakan dalam perancangan tampilan user interface berdasarkan tahapan langkah-langkah yang sesuai dalam mencapai tujuannya yaitu merancang interface yang efektif dan sesuai kebutuhan pengguna. Adapun tahapan yang dilalui ialah Research, Modeling, Requirements, Framework, dan Refinement. Setelah melakukan penelitian dengan mengikuti metode maka selanjutnya tahap evaluasi. Penelitian ini menggunakan evaluasi heuristik dimana evaluasi ini baik dalam menemukan masalah kegunaan yang ada pada user interface yang dirancang. Evaluasi dilakukan dengan menyebarkan kuesioner kepada para ahli dengan menggunakan skala likert. Setelah melakukan penelitian dengan mengikuti metode dan evaluasi yang digunakan, maka didapatkan hasil evaluasi perancangan adalah $94 \%$ dimana hasil tersebut termasuk dalam kategori "Sangat Baik" sebagai desain perancangan user interface sistem transaksi online pasar tradisional.

\section{SARAN}

Saran yang dapat peneliti berikan dari penelitian ini dan yang diharapkan dapat dilakukan selanjutnya ialah sebagai berikut:
1. Melakukan pengembangan sistem secara keseluruhan sampai sistem dapat diimplementasikan dengan data yang sebenarnya.

2. Penelitian selanjutnya setelah diimplementasikan maka dapat melanjutkan ke tahap selanjutnya yaitu tahapan support dalam metode GDD.

3. Penelitian selanjutnya pada tahap evaluasi disarankan untuk mengevaluasi dengan metode yang berbeda atau dapat melakukan perbandingan evaluasi.

\section{DAFTAR PUSTAKA}

Fatra, M. 2018. Analisis preferensi konsumen berbelanja di pasar tradisional dan pasar modern di kota makassar. Skripsi

Guspul, A. 2015. Persepsi Konsumen Terhadap Pasar Tradisonal dan Pasar Modern: Marketing Mix (Studi Kasus Pada Pasar Tradisional "Pasar Induk Wonosobo" Dan Pasar Modern "Rita Pasar Raya Wonosobo"). Ppkm Iii, 228240.

Jahja, A. S. (2017, Oktober 30). Berapa Jumlah Informan Riset Kualitatif. (Perbanas Institute) Retrieved November 13, 2018, from https://dosen.perbanas.id/berapajumlah-informan-riset-kualitatif/

Nielsen, J. (1994, November 1). Retrieved Desember 19, 2018, from https://www.nngroup.com/articles/howto-conduct-a-heuristic-evaluation/

Neilsen, J. (1994). M4 L4 Nielsen's Ten Heuristics. Computer Science Engineering- Human Cumputer Interaction, 1-6.

Novita, D., Amanati, R., \& Aldy, P. 2017. Pasar Tradisional di Pekan Baru dengan Pendekatan Arsitektur Tropis. Jom FTEKNIK, 1(1), 1-9.

Sabariah, M. K., Denis O.W, I. N., Jatmiko S., D. D. (2016). Rekomendasi User Interface Untuk Aplikasi Mobile Seleksi Mahasiswa Baru (SMB) Telkom Menggunakan Metode Goal Directed Design, 2(2), 6656-6664. https://doi.org/10.21108/indosc.2015.11 